\title{
Simulation of Tri-Reforming Reaction Using Flue Gases of Thermal Power Plant (Natural Gas Fired)
}

\author{
Sheeba Jilani and Anil Kumar \\ Department of Chemical Engineering, \\ Aligarh Muslim University, Aligarh, India
}

\begin{abstract}
This work outlines the modeling aspects of kinetic evaluation for tri-reforming of methane (TRM), by using flue gases of thermal power plant(natural gas fired). The results figure out tri-reforming to be the most synergetic process as being combination of steam reforming, partial oxidation of methane and dry reforming $\left(\mathrm{CO}_{2}\right.$ reforming). This not only produces synthesis gas $\left(\mathrm{CO}+\mathrm{H}_{2}\right)$ with desired $\mathrm{H}_{2} / \mathrm{CO}$ ratios (1.1-2) but also results in higher values of conversion for methane and carbon dioxide. These two advantages have been demonstrated by tri-reforming of $\mathrm{CH}_{4}$ in a fixed-bed flow reactor at $1123 \mathrm{~K}$ with supported nickel catalysts. Over $97 \%$ $\mathrm{CH}_{4}$ conversion and about $67.83 \% \mathrm{CO}_{2}$ conversion can be achieved in tri-reforming over $\mathrm{Ni} / \mathrm{Al}_{2} \mathrm{O}_{3}$ catalysts. Modeling equations were solved simultaneously using ordinary differential equation solver "ode 45" in MATLAB 9.0. Trireforming is more desired for producing syngas with desired $\mathrm{H}_{2} / \mathrm{CO}$ ratios of 1.1-2.0 compared to $\mathrm{CO}_{2}$ reforming, steam reforming and partial oxidation of methane. Moreover, trireforming of methane can be achieved successfully with high conversion (>97\%) and high $\mathrm{CO}_{2}$ conversion (>67\%) for producing syngas with desired $\mathrm{H}_{2} / \mathrm{CO}$ ratios of $1-2$ over supported nickel catalyst at $1123 \mathrm{~K}$ under atmospheric pressure.
\end{abstract}

Keywords: tri reforming, syngas production, flue gas

\section{INTRODUCTION}

Tri-reforming is a new process designed for the direct production of synthesis gas with desirable $\mathrm{H}_{2} / \mathrm{CO}$ ratios by reforming methane or natural gas using flue gas from fossil fuel based electric power plants without pre-separation of $\mathrm{CO}_{2}$. The combination of dry reforming with steam reforming can accomplish two important missions to produce syngas with desired $\mathrm{H}_{2} / \mathrm{CO}$ ratios and to mitigate the carbon formation problem that is significant for dry reforming [Chunshan Song and Wei Pan (2004) ]. Integrating steam reforming and partial oxidation with $\mathrm{CO}_{2}$ reforming could dramatically reduce or eliminate carbon formation on reforming catalyst thus increase catalyst life and process efficiency. Therefore, the proposed tri-reforming can solve two important problems that are encountered in individual processing. The incorporation of $\mathrm{O}_{2}$ in the reaction generates heat in situ that can be used to increase energy efficiency and $\mathrm{O}_{2}$ also reduces or eliminates the carbon formation on the reforming catalyst.

Wei Pan et. al. (2002) the current major applications of synthesis gas include methanol synthesis and Fischer-Tropsch (F-T) synthesis that require synthesis gas with a $\mathrm{H}_{2} / \mathrm{CO}$ ratio close to 2. However, synthesis gas directly produced from $\mathrm{CO}_{2}$ reforming of methane has $\mathrm{H}_{2} / \mathrm{CO}$ ratio close to 1 . Hence this kind of synthesis gas $\left(\mathrm{H}_{2} / \mathrm{CO}\right.$ ratio $\left.\leq 1\right)$ requires further treatment in order to be applied in methanol and F-T synthesis. Similarly synthesis gas produced from steam reforming can not be directly applied in methanol or F-T synthesis either since the $\mathrm{H}_{2} / \mathrm{CO}$ ratio of synthesis gas produced from steam reforming is usually larger than 3 . Although methane partial oxidation produces synthesis gas with a $\mathrm{H}_{2} / \mathrm{CO}$ ratio of 2 , methane partial oxidation is difficult to control due to its exothermic feature and that is dangerous and expensive due to the handling of pure oxygen. Tri reforming, however, is expected to readily produce synthesis gas with the desired $\mathrm{H}_{2} / \mathrm{CO}$ ratios of $1.5 \sim 2$ by manipulating tri reforming reactant compositions under relatively mild reaction conditions.

The tri-reforming can thus be achieved with natural gas and flue gases using the 'waste heat' in the power plant and the heat generated in situ from oxidation with the $\mathrm{O}_{2}$ that is already present in flue gas. Tri-reforming consume more energy than steam or dry reforming. M. Halmann et. al. (2009) thermo-chemical equilibrium calculations along with mass/energy balances indicate that for flue-gas treatment by tri-reforming, $\mathrm{CO}_{2}$ emission avoidance of up to $59 \%$ and fossil fuel savings of up to $75 \%$ may be attained when concentrated solar energy is supplied as high-temperature process heat for the calcination step, all relative to conventional $\mathrm{H}_{2}$ production by coal gasification. If instead fossil fuel would be used to drive the calcination step, the $\mathrm{CO}_{2}$ emission avoidance and the fuel savings would be only $20 \%$ and $67 \%$, respectively.

Flue gases from fossil fuel-based electricity-generating units are the major concentrated $\mathrm{CO}_{2}$ sources. If $\mathrm{CO}_{2}$ is to be 
separated, as much as 100 megawatts of a typical 500 megawatt coal fired power plant would be necessary for today's $\mathrm{CO}_{2}$ capture processes based on the alkanol amines (Chunshan Song and Wei Pan 2004). Therefore, it would be highly desirable if the flue gas mixtures can be used for $\mathrm{CO}_{2}$ conversion but without pre-separation of $\mathrm{CO}_{2} \cdot \mathrm{CO}_{2}$ conversion and utilization should be an integral part of $\mathrm{CO}_{2}$ management, although the amount of $\mathrm{CO}_{2}$ that can be used for making industrial chemicals is small compared to the quantity of flue gas. Typical flue gases from coal-fired power plants may contain $13 \% \mathrm{CO}_{2}, 9 \% \mathrm{H}_{2} \mathrm{O}, 4 \% \mathrm{O}_{2}$, and $74 \% \mathrm{~N}_{2}$; typical flue gases from natural gas-fired boilers may contain 9 vol\% $\mathrm{CO}_{2}$, 19 vol $\% \mathrm{H}_{2} \mathrm{O}, 2.5$ vol $\% \mathrm{O}_{2}$ and $69.5 \% \mathrm{~N}_{2}$. The typical furnace outlet temperature of flue gases is usually around $1200^{\circ} \mathrm{C}$ which will decreases gradually along the pathway of heat transfer, while the temperature of the flue gases going to stack is around $150{ }^{\circ} \mathrm{C}$. Pollution control technologies can remove the SOx, NOx and particulate matter effectively, but $\mathrm{CO}_{2}$ and $\mathrm{H}_{2} \mathrm{O}$ as well as $\mathrm{O}_{2}$ remain largely unchanged. The composition of flue gases depends on the types of fossile fuels used in power pants.

Table 1.2: M Halmann et. al. (2006)

\begin{tabular}{|l|l|l|l|}
\hline $\begin{array}{l}\text { Natural Gas Fired } \\
\text { Power Plant (volume) }\end{array}$ & \multicolumn{2}{|l|}{$\begin{array}{l}\text { Coal Fired Power } \\
\text { Plant (volume) }\end{array}$} \\
\hline $\mathrm{CO}_{2}$ & $9 \%$ & $\mathrm{CO}_{2}$ & $13 \%$ \\
\hline $\mathrm{H}_{2} \mathrm{O}$ & $19 \%$ & $\mathrm{H}_{2} \mathrm{O}$ & $9 \%$ \\
\hline $\mathrm{O}_{2}$ & $2.5 \%$ & $\mathrm{O}_{2}$ & $4 \%$ \\
\hline $\mathrm{N}_{2}$ & $69.5 \%$ & $\mathrm{~N}_{2}$ & $74 \%$ \\
\hline
\end{tabular}

\section{CHEMICAL REACTION}

Tri-reforming is a synergetic combination of endothermic $\mathrm{CO}_{2}$ reforming (eq. 1) and steam reforming (eq. 2) and exothermic partial oxidation of methane (eq. 3 , eq. 4). $\mathrm{CO}_{2}, \mathrm{H}_{2} \mathrm{O}$ and $\mathrm{O}_{2}$ in the waste flue gas from fossil-fuel-based power plants will be utilized as co reactants for tri-reforming of natural gas for the production of synthesis gas. The new process is called trireforming of methane.

\section{Tri-reforming of Natural Gas}

$$
\begin{array}{lc}
\mathrm{CH}_{4}+\mathrm{CO}_{2}=2 \mathrm{CO}+2 \mathrm{H}_{2} & {\left[\Delta \mathrm{H}^{\circ}=247.3 \mathrm{~kJ} / \mathrm{mol}\right]} \\
\mathrm{CH}_{4}+\mathrm{H}_{2} \mathrm{O}=\mathrm{CO}+3 \mathrm{H}_{2} & {\left[\Delta \mathrm{H}^{\circ}=206.3 \mathrm{~kJ} / \mathrm{mol}\right]} \\
\mathrm{CH}_{4}+1 / 2 \mathrm{O}_{2}=\mathrm{CO}+2 \mathrm{H}_{2} & {\left[\Delta \mathrm{H}^{\circ}=-35.6 \mathrm{~kJ} / \mathrm{mol}\right]} \\
\mathrm{CH}_{4}+2 \mathrm{O}_{2}=\mathrm{CO} 2+2 \mathrm{H}_{2} \mathrm{O} & {\left[\Delta \mathrm{H}^{\circ}=-880 \mathrm{~kJ} / \mathrm{mol}\right]}
\end{array}
$$

\section{Reactions for Coke Formation and Destruction}

$$
\begin{array}{ll}
\mathrm{CH}_{4}=\mathrm{C}+2 \mathrm{H}_{2} & {\left[\Delta \mathrm{H}^{\circ}=74.9 \mathrm{~kJ} / \mathrm{mol}\right]} \\
2 \mathrm{CO}=\mathrm{C}+\mathrm{CO}_{2} & {\left[\text { Exo: } \Delta \mathrm{H}^{\circ}=-172.2 \mathrm{~kJ} / \mathrm{mol}\right]} \\
\mathrm{C}+\mathrm{CO}_{2}=2 \mathrm{CO} & {\left[\text { Endo: } \Delta \mathrm{H}^{\circ}=172.2 \mathrm{~kJ} / \mathrm{mol}\right]} \\
\mathrm{C}+\mathrm{H}_{2} \mathrm{O}=\mathrm{CO}+\mathrm{H}_{2} & {\left[\text { Endo: } \Delta \mathrm{H}^{\circ}=131.4 \mathrm{~kJ} / \mathrm{mol}\right]} \\
\mathrm{C}+\mathrm{O}_{2}=\mathrm{CO}_{2} & {\left[\text { Exo: } \Delta \mathrm{H}^{\circ}=-393.7 \mathrm{~kJ} / \mathrm{mol}\right]}
\end{array}
$$

\section{MODEL DEVELOPMENT}

The conversion of natural gas was carried out via trireforming of methane in a fixed bed reactor employing a $\mathrm{Ni} / \gamma$ $\mathrm{Al}_{2} \mathrm{O}_{3}$ catalyst. The effects due to water and oxygen addition to the feed of the process were examined in terms of the yields of hydrogen and carbon monoxide.The kinetic model for trireforming was developed considering a fixed bed reactor $\left(\mathrm{h}_{\text {reactor }}=0.64 \mathrm{~m}, \quad \mathrm{~h}_{\text {bed }}=0.02 \mathrm{~m}, \quad \mathrm{~d}_{\text {reactor }}=212 \mu \mathrm{m}\right) \quad$ under atmospheric pressure and temperature of $1123 \mathrm{~K}$ on nickel catalyst bed on gamma-aluminum tri-oxide $\operatorname{support}(\mathrm{Ni} / \gamma$ $\mathrm{Al}_{2} \mathrm{O}_{3}$ ) .The ratio of mixture of reactants of feed(natural gas,NG) was considered as $\mathrm{CH}_{4}: \mathrm{CO}_{2}: \mathrm{H}_{2} \mathrm{O}: \mathrm{O}_{2} / 1.0: 0.49: 0.30: 0.04 \mathrm{v} / \mathrm{v}$ and feed flow rate of $11.67 \mathrm{~cm}^{3} / \mathrm{s}$ was taken for the reforming processes.

\subsection{KINETIC MODEL FOR TRI-REFORMING}

Tri-reforming is a synergetic combination of endothermic $\mathrm{CO}_{2}$ reforming, and steam reforming and exothermic oxidation of methane. With this process concept, $\mathrm{CO}_{2}, \mathrm{H}_{2} \mathrm{O}$, and $\mathrm{O}_{2}$ in the flue gas from fossil-fuel-based power plants can be utilized as co-reactants for tri-reforming of natural gas for the production of synthesis gas. The set of reactions for the process are given below:

$\mathrm{CH}_{4}(\mathrm{~g})+5 / 8 \mathrm{O}_{2}(\mathrm{~g}) \leftrightarrow \mathrm{CO}(\mathrm{g})+7 / 4 \mathrm{H}_{2}(\mathrm{~g})+1 / 4 \mathrm{H}_{2} \mathrm{O}(\mathrm{g})$

$\mathrm{CH}_{4}(\mathrm{~g}) \rightarrow \mathrm{C}(\mathrm{s})+2 \mathrm{H}_{2}(\mathrm{~g}) \quad$ (methane cracking reaction)

$2 \mathrm{CO}(\mathrm{g}) \rightarrow \mathrm{C}(\mathrm{s})+\mathrm{CO}_{2}(\mathrm{~g}) \quad$ (Boudouard reaction)

$\mathrm{CO}_{2}(\mathrm{~g})+\mathrm{H}_{2}(\mathrm{~g}) \rightarrow \mathrm{CO}(\mathrm{g})+\mathrm{H}_{2} \mathrm{O}(\mathrm{g})$

(Reverse water-gas shift reaction)

The kinetic model for the reactions on $\mathrm{Ni} / \gamma-\mathrm{Al}_{2} \mathrm{O}_{3}$ by following reaction mechanism in which the rate expressions for reactions (1) - (4) are given by:

$$
\begin{aligned}
& \mathrm{r}_{1}=\frac{\mathrm{k}_{1} \mathrm{~K}_{\mathrm{CH}_{4}} \mathrm{C}_{\mathrm{CH}_{4}} \mathrm{~K}_{\mathrm{O}_{2}} \mathrm{C}_{\mathrm{O}_{2}}}{\left(1+\mathrm{K}_{\mathrm{CH}_{4}} \mathrm{C}_{\mathrm{CH}_{4}}+\mathrm{K}_{\mathrm{O}_{2}} \mathrm{C}_{\mathrm{O}_{2}}\right)} \\
& \mathrm{r}_{2}=\frac{\mathrm{k}_{2} \mathrm{~K}_{\mathrm{CH}_{4}} \mathrm{C}_{\mathrm{CH}_{4}}}{\left(1+\mathrm{K}_{\mathrm{CH}_{4}} \mathrm{C}_{\left.\mathrm{CH}_{4}\right)}\right.} \\
& \mathrm{r}_{\mathrm{a}}=\mathrm{k}_{\mathrm{a}} \mathrm{C}_{\mathrm{CO}}^{2} \\
& \mathrm{r}_{4}=\left(\mathrm{C}_{\mathrm{H}_{2}} \mathrm{C}_{\mathrm{CO}_{2}}-\frac{\mathrm{COO}_{\mathrm{CO}} \mathrm{C}_{\mathrm{H}_{2} \mathrm{O}}}{\mathrm{K}_{\mathrm{sq}}}\right)
\end{aligned}
$$


The component relations $\mathrm{R}_{\mathrm{i}}\left(\mathrm{i}=\mathrm{CH}_{4}, \mathrm{CO}_{2}, \mathrm{CO}, \mathrm{H}_{2}\right)$, based on rate laws of the four step reaction proposed above, are considered as:

$$
\begin{aligned}
& \mathrm{R}_{\mathrm{CH}_{4}}=-\mathrm{r}_{1}-\mathrm{r}_{2}, \mathrm{R}_{\mathrm{CO}_{2}}=\mathrm{r}_{3}-\mathrm{r}_{4}, \\
& \mathrm{R}_{\mathrm{H}_{2}}=\frac{\bar{T}}{4} \mathrm{r}_{1}-2 \mathrm{r}_{2}-\mathrm{r}_{4}, \mathrm{R}_{\mathrm{CO}}=\mathrm{r}_{1}-2 \mathrm{r}_{3}+\mathrm{r}_{4}
\end{aligned}
$$

The mass balances of the components are expressed as $\frac{d c_{\mathrm{i}}}{d t}+R_{\mathrm{i}}=0$, where $\mathrm{t}$ (minutes) is the time.

$$
\begin{aligned}
& \frac{\mathrm{dC}_{\mathrm{CH}_{4}}}{\mathrm{dt}}=-\frac{\mathrm{k}_{1} \mathrm{~K}_{\mathrm{CH}_{4}} \mathrm{C}_{\mathrm{CH}_{4}} \mathrm{~K}_{\mathrm{O}_{2}} \mathrm{C}_{\mathrm{O}_{2}}}{\left(1+\mathrm{K}_{\mathrm{CH}_{4}} \mathrm{C}_{\mathrm{CH}_{4}}+\mathrm{K}_{\mathrm{O}_{2}} \mathrm{C}_{\mathrm{O}_{2}}\right)}-\frac{\mathrm{k}_{2} \mathrm{~K}_{\mathrm{CH}_{4}} \mathrm{C}_{\mathrm{CH}_{4}}}{\left(1+\mathrm{K}_{\mathrm{CH}_{4}} \mathrm{C}_{\mathrm{CH}_{4}}\right)} \\
& \frac{\mathrm{dC}_{\mathrm{CO}_{2}}}{\mathrm{dt}}=\mathrm{k}_{\mathrm{a}} \mathrm{C}_{\mathrm{CO}}^{2}-\left(\mathrm{C}_{\mathrm{H}_{2}} \mathrm{C}_{\mathrm{CO}_{2}}-\frac{\mathrm{C}_{\mathrm{CO} \mathrm{C}_{\mathrm{H}_{2} \mathrm{O}}}}{\mathrm{K}_{\mathrm{eq}}}\right)
\end{aligned}
$$

$$
\begin{aligned}
\frac{\mathrm{dC}_{\mathrm{H}_{2}}=}{\mathrm{dt}}= & \frac{7}{4} \frac{\mathrm{k}_{1} \mathrm{~K}_{\mathrm{CH}_{4}} \mathrm{C}_{\mathrm{CH}_{4}} \mathrm{~K}_{\mathrm{O}_{2}} \mathrm{C}_{\mathrm{O}_{2}}}{\left(1+\mathrm{K}_{\mathrm{CH}_{4}} \mathrm{C}_{\mathrm{CH}_{4}}+\mathrm{K}_{\mathrm{O}_{2}} \mathrm{C}_{\mathrm{O}_{2}}\right)} \\
& -2 \frac{\mathrm{k}_{2} \mathrm{~K}_{\mathrm{CH}_{4}} \mathrm{C}_{\mathrm{CH}_{4}}}{\left(1+\mathrm{K}_{\mathrm{CH}_{4}} \mathrm{C}_{\left.\mathrm{CH}_{4}\right)}\right.}-\left(\mathrm{C}_{\mathrm{H}_{2}} \mathrm{C}_{\mathrm{CO}_{2}}-\frac{\mathrm{C}_{\mathrm{CO} \mathrm{C}_{\mathrm{H}_{2} \mathrm{O}}}}{\mathrm{K}_{\mathrm{eq}}}\right)
\end{aligned}
$$

$$
\begin{aligned}
\frac{\mathrm{dC}}{\mathrm{dt}} & =\frac{\mathrm{k}_{1} \mathrm{~K}_{\mathrm{CH}_{4}} \mathrm{C}_{\mathrm{CH}_{4}} \mathrm{~K}_{\mathrm{O}_{2}} \mathrm{C}_{\mathrm{O}_{2}}}{\left(1+\mathrm{K}_{\mathrm{CH}_{4}} \mathrm{C}_{\mathrm{CH}_{4}}+\mathrm{K}_{\mathrm{O}_{2}} \mathrm{C}_{\mathrm{O}_{2}}\right)} \\
& -2 \mathrm{k}_{2} \mathrm{C}_{\mathrm{CO}}^{2}+\left(\mathrm{C}_{\mathrm{H}_{2}} \mathrm{C}_{\mathrm{CO}_{2}}-\frac{\mathrm{COO}_{\mathrm{CO}_{\mathrm{H}} \mathrm{O}} \mathrm{C}_{\mathrm{H}_{2}}}{\mathrm{~K}_{\mathrm{eq}}}\right)
\end{aligned}
$$

The mass balances of the components are obtained in terms of reactor length as $\frac{\mathrm{dP}_{\mathrm{i}}}{\mathrm{dz}}+\mathrm{R}_{\mathrm{i}}=0$, where $\mathrm{z}$ (meters), is the reactor length.

$\mathrm{t}=\frac{\mathrm{mr}_{1}^{2} \mathrm{z}}{\mathrm{F}}$,

(3.13) where $r_{1}=$ radius of reactor, $F$ is the volumetric flow rate of feed

$$
\begin{aligned}
& \frac{\mathrm{dC}_{\mathrm{CH}_{4}}}{\mathrm{dz}}=\left(\frac{\mathrm{F}}{\mathrm{rr}_{1}^{2}}\right)\left[-\frac{\mathrm{k}_{1} \mathrm{~K}_{\mathrm{CH}_{4}} \mathrm{C}_{\mathrm{CH}_{4}} \mathrm{~K}_{\mathrm{O}_{2}} \mathrm{C}_{\mathrm{O}_{2}}}{\left(1+\mathrm{K}_{\mathrm{CH}_{4}} \mathrm{C}_{\mathrm{CH}_{4}}+\mathrm{K}_{\mathrm{O}_{2}} \mathrm{C}_{\mathrm{O}_{2}}\right)}-\frac{\mathrm{k}_{2} \mathrm{~K}_{\mathrm{CH}_{4}} \mathrm{C}_{\mathrm{CH}_{4}}}{\left(1+\mathrm{K}_{\mathrm{CH}_{4}} \mathrm{C}_{\mathrm{CH}_{4}}\right)}\right] \\
& \frac{\mathrm{dC}_{\mathrm{CO}_{2}}}{\mathrm{dz}}=\left(\frac{\mathrm{F}}{\mathrm{mr}_{1}^{2}}\right)\left[\mathrm{k}_{\mathrm{a}} \mathrm{C}_{\mathrm{CO}}^{2}-\left(\mathrm{C}_{\mathrm{H}_{2}} \mathrm{C}_{\mathrm{CO}_{2}}-\frac{\mathrm{c}_{\mathrm{Co}^{2} \mathrm{C}_{\mathrm{H}_{2} \mathrm{O}}}}{\mathrm{K}_{\mathrm{eq}}}\right)\right] \\
& \frac{\mathrm{dC}_{\mathrm{H}_{2}}}{\mathrm{dz}}=\left(\frac{\mathrm{F}}{\mathrm{mr} r_{1}^{2}}\right)\left[\frac{\mathrm{J}}{4} \frac{\mathrm{k}_{1} \mathrm{~K}_{\mathrm{CH}_{4}} \mathrm{C}_{\mathrm{CH}_{4}} \mathrm{~K}_{\mathrm{O}_{2}} \mathrm{C}_{\mathrm{O}_{2}}}{\left(1+\mathrm{K}_{\mathrm{CH}_{4}} \mathrm{C}_{\mathrm{CH}_{4}}+\mathrm{K}_{\mathrm{O}_{2}} \mathrm{C}_{\mathrm{D}_{2}}\right)}\right. \\
& \left.-2 \frac{\mathrm{k}_{2} \mathrm{~K}_{\mathrm{CH}_{4}} \mathrm{C}_{\mathrm{CH}_{4}}}{\left(1+\mathrm{K}_{\mathrm{CH}_{4}} \mathrm{C}_{\left.\mathrm{CH}_{4}\right)}\right.}-\left(\mathrm{C}_{\mathrm{H}_{2}} \mathrm{C}_{\mathrm{CO}_{2}}-\frac{\mathrm{C}_{\mathrm{CO} \mathrm{C}_{\mathrm{H}_{2} \mathrm{O}}}}{\mathrm{K}_{\mathrm{eq}}}\right)\right]
\end{aligned}
$$

$$
\begin{aligned}
\frac{d C_{\mathrm{CO}}}{\mathrm{dz}} & =\left(\frac{\mathrm{F}}{\mathrm{rr}_{1}^{2}}\right)\left[\frac{\mathrm{k}_{1} \mathrm{~K}_{\mathrm{CH}_{4}} \mathrm{C}_{\mathrm{CH}_{4}} \mathrm{~K}_{\mathrm{D}_{2}} \mathrm{C}_{\mathrm{O}_{2}}}{\left(1+\mathrm{K}_{\mathrm{CH}_{4}} \mathrm{C}_{\mathrm{CH}_{4}}+\mathrm{K}_{\mathrm{O}_{2}} \mathrm{C}_{\mathrm{O}_{2}}\right)}-\right. \\
& \left.-2 \mathrm{k}_{2} \mathrm{C}_{\mathrm{CO}}^{2}+\left(\mathrm{C}_{\mathrm{H}_{2}} \mathrm{C}_{\mathrm{CO}_{2}}-\frac{\mathrm{C}_{\mathrm{CO} \mathrm{C}} \mathrm{C}_{\mathrm{H}_{2} \mathrm{O}}}{\mathrm{K}_{\mathrm{eq}}}\right)\right]
\end{aligned}
$$

The solutions of the mass balance equations system were obtained with the 4th order Runge-Kutta method with the

\begin{tabular}{|c|c|}
\hline Parameters & Pre-exponential factor \\
\hline $\mathbf{k}_{1}$ & $1.21 \pm 0.06 \times 10^{-1} \mathrm{~mol} / \mathrm{g}_{\text {cat }} . \mathrm{S}$ \\
\hline $\mathbf{k}_{2}$ & $3.91 \pm 0.16 \times 10^{-4} \mathrm{~mol} / \mathrm{g}_{\text {cat }} . \mathrm{S}$ \\
\hline $\mathbf{k}_{3}$ & $7.32 \pm 0.32 \times 10^{-2} \mathrm{~m}^{3} /$ mol.gcat.s \\
\hline k4 & $1.04 \pm 0.05 \times 10^{-4} \mathrm{~mol} /$ geat. $\mathrm{S}$ \\
\hline $\mathrm{K}_{\mathrm{CH} 4}$ & $2.93 \pm 0.11 \times 10^{-3} \mathrm{~m}^{3} / \mathrm{mol}$ \\
\hline $\mathrm{K}_{\mathrm{O} 2}$ & $3.53 \pm 0.15 \times 10^{5} \mathrm{~m}^{3} / \mathrm{mol}$ \\
\hline $\mathbf{K}_{\mathrm{eq}}$ & $1.07 \pm 0.06 \times 10^{3} \mathrm{~m}^{3} / \mathrm{mol}$ \\
\hline
\end{tabular}
help of ODE-45 solver from MATLAB toolbox.

\subsection{SOLUTION PROCEDURE}

Considering the reaction mechanism of the four reaction mechanisms, indicated as the observed reaction steps, expressions of rate laws to the components were derived in order to yield mass balances for the four components namely methane $\left(\mathrm{CH}_{4}\right)$, carbon dioxide $\left(\mathrm{CO}_{2}\right)$, carbon monoxide $(\mathrm{CO})$ and hydrogen $\left(\mathrm{H}_{2}\right)$.the mass balances were derived with respect to time and length of the reactor. The solutions obtained set of mass balance equations for each reforming process were obtained by the help of ordinary differential equations solver "ODE 45" in MATLAB 9.

\section{Model Parameters For Tri-Reforming}

\section{SIMULATION RESULTS}

The MATLAB programs incorporated four set of following equations framed for each component namely, Methane, Carbon Dioxide, Carbon Monoxide and Hydrogen.

ODE's for concentration variations with respect to time ODE's for concentration variations with respect to length ODE's for conversion variations with respect to time ODE's for conversion variations with respect to length ODE's for Hydrogen to Methane ratio with respect to length

ODE's for Hydrogen to Methane ratio with respect to time 


\subsection{PLOTS FOR SIMULATED RESULTS}

$\mathrm{CH}_{4}$ CONC. VS TIME (TRM)

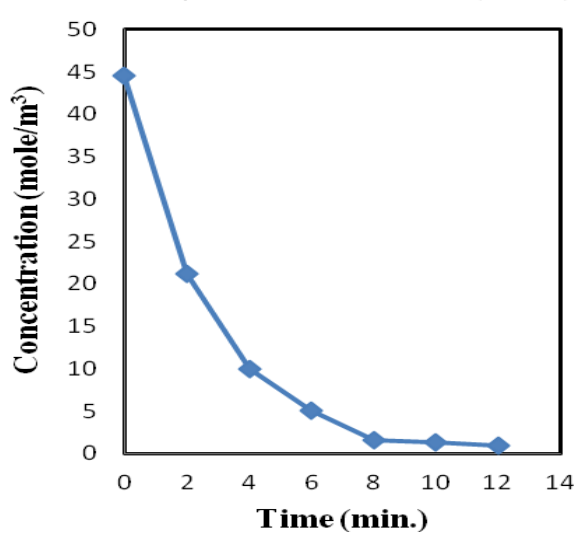

Fig 4.1 Methane Concentration versus Time Plots

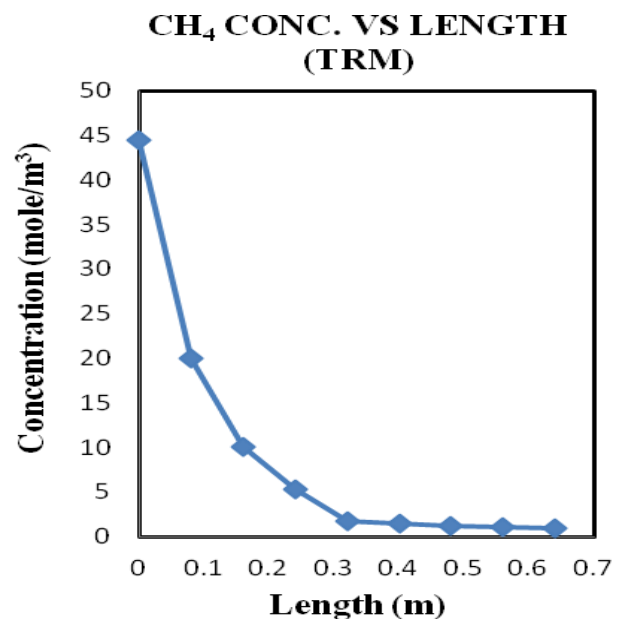

Fig 4.2 Methane Concentration versus Length Plots

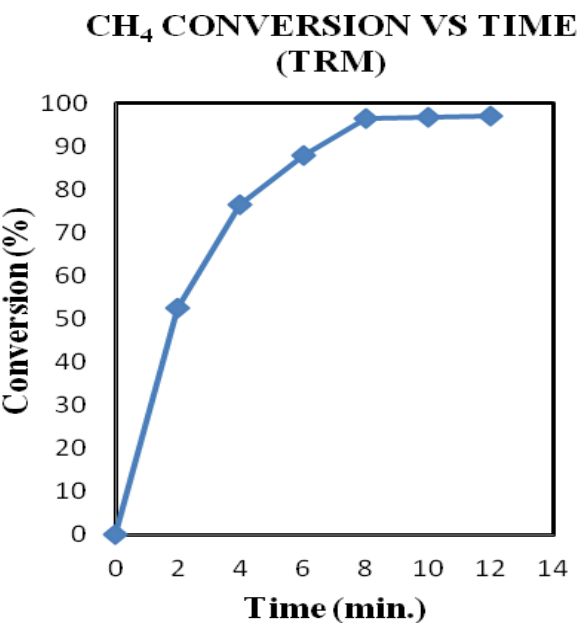

Fig 4.3 Methane Conversion versus Time Plots

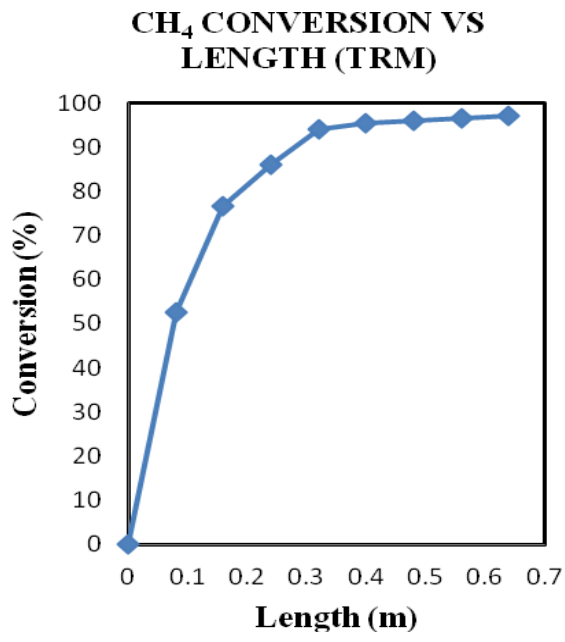

Fig 4.4 Methane Conversion versus Length Plots

$\mathrm{CO}_{2} \mathrm{CONC}$. VS TIME (TRM)

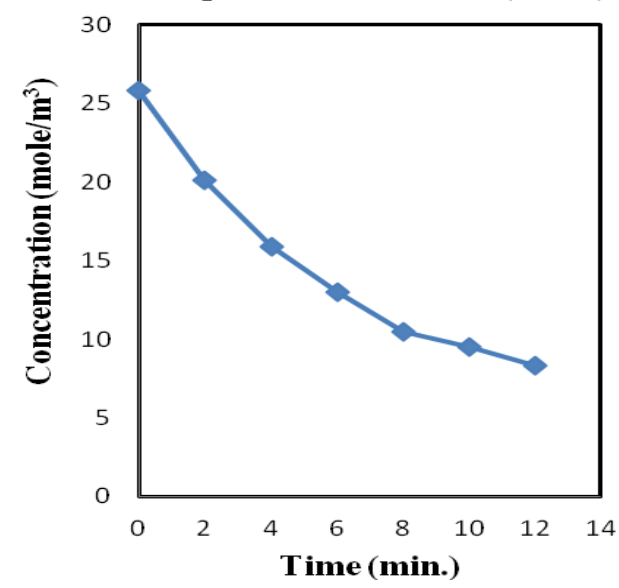

Fig 4.5 Carbon Dioxide Concentration versus Time Plots $\mathrm{CO}_{2}$ CONC. VS LENGTH (TRM)

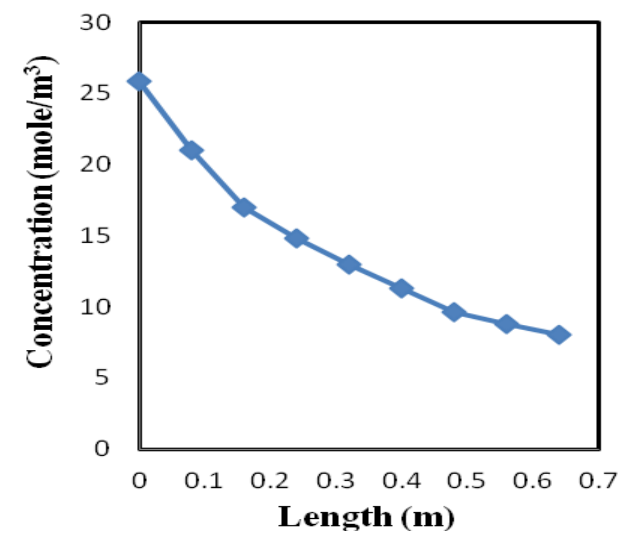

Fig 4.6 Carbon Dioxide Concentration versus Length Plots 


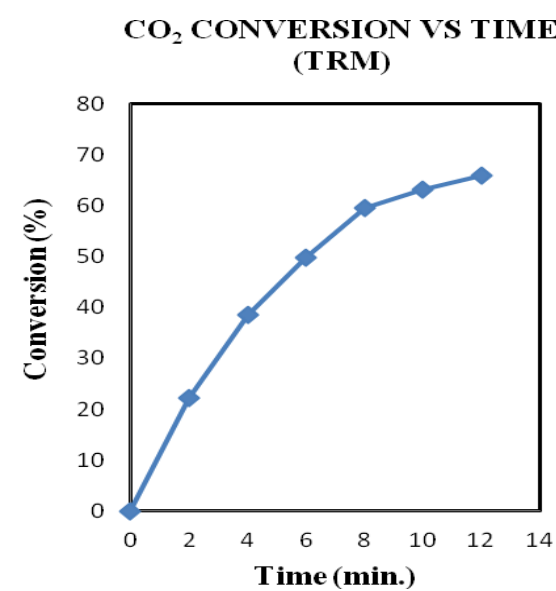

Fig 4.7 Carbon Dioxide Conversion versus Time Plots

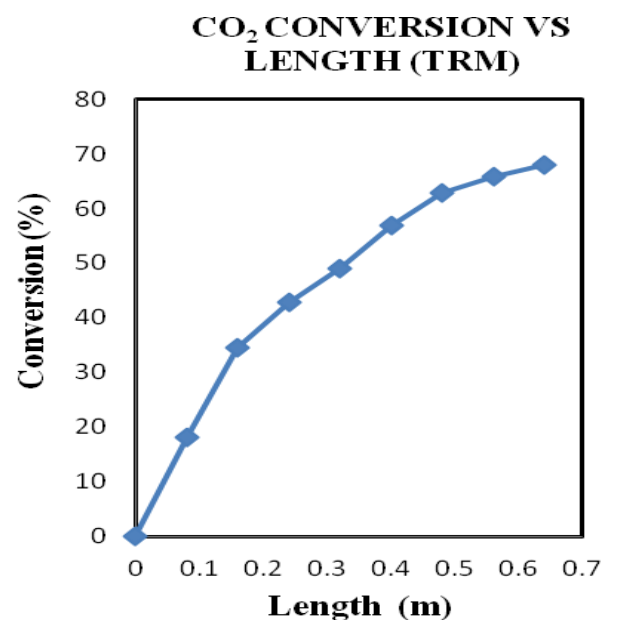

Fig 4.8 Carbon Dioxide Conversion versus Length Plots

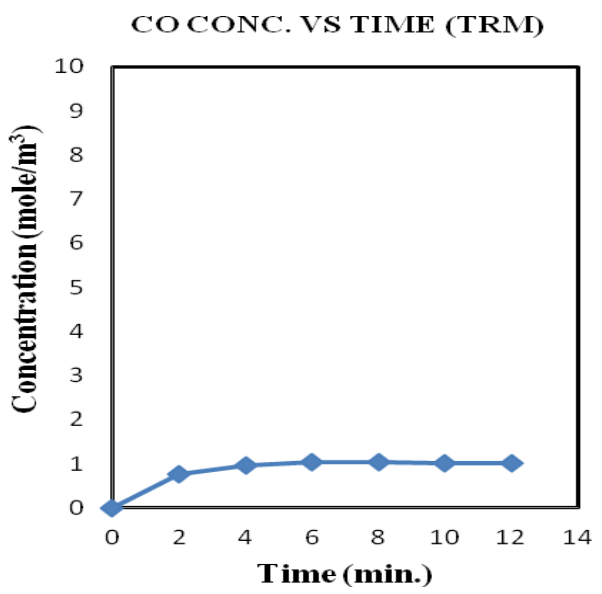

Fig 4.9 Carbon Monoxide Concentration versus Time Plots

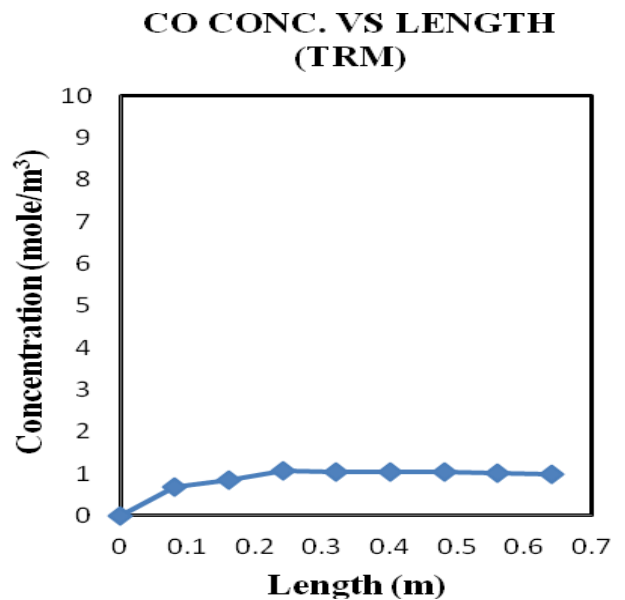

Fig 4.10 Carbon Monoxide Concentration versus Length Plots

$\mathrm{H}_{2}$ CONC. VS TIME (TRM)

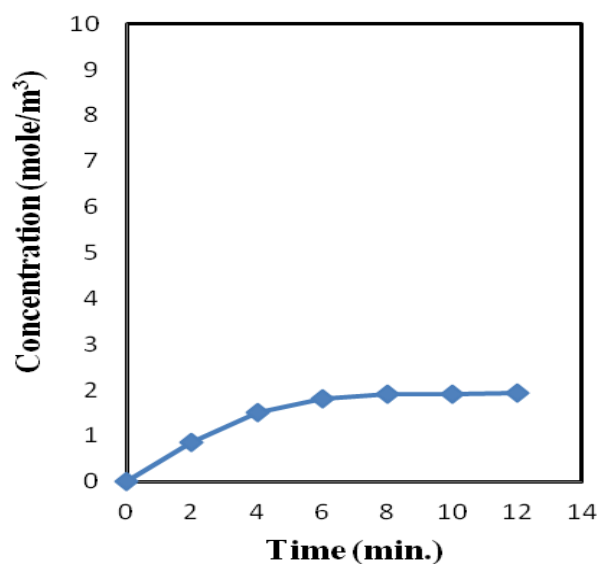

Fig 4.11 Hydrogen Concentration versus Time Plots

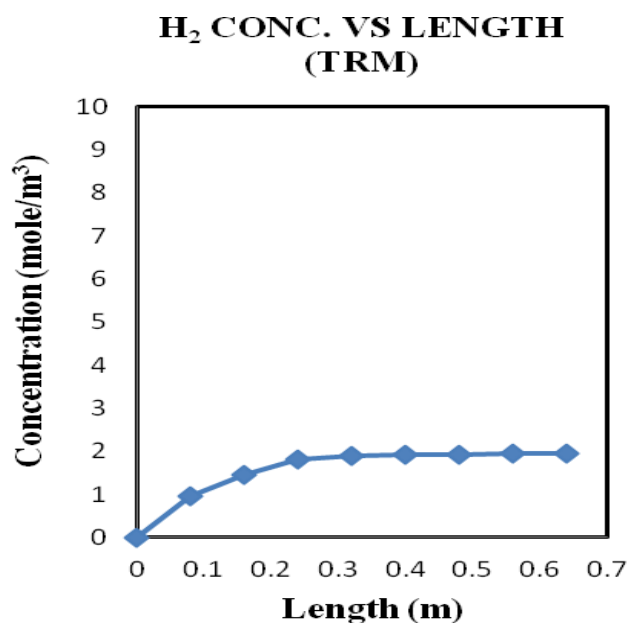

Fig 4.12 Hydrogen Concentration versus Length Plot 
H $_{2}$ /CO RATIO VS TIME (TRM)

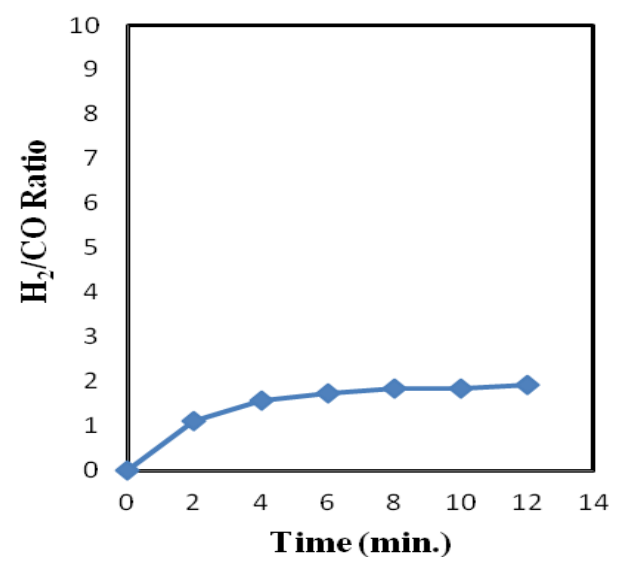

Fig 4.13 Hydrogen to Carbon Monoxide Ratio versus Time Plots

\section{H $_{2} /$ CO RATIO VS LENGTH} (TRM)

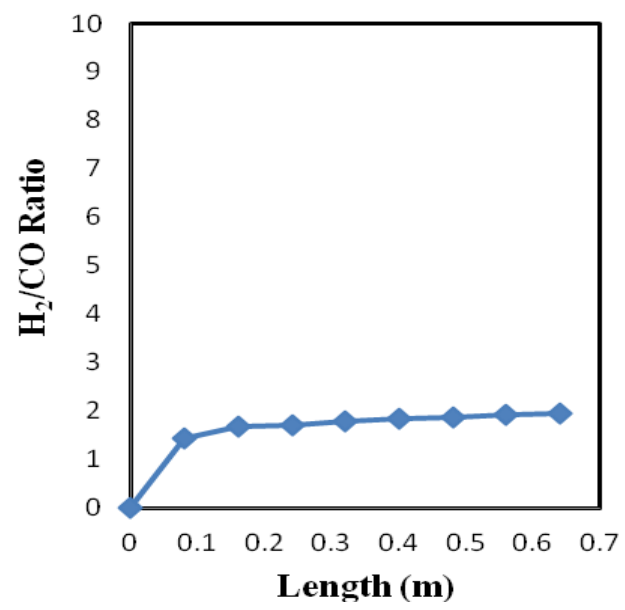

Fig 4.14 Hydrogen to Carbon Monoxide Ratio versus Length Plots

\subsection{DISCUSSION}

A modeling study of kinetics of processes of steam reforming, dry reforming, partial oxidation of methane and tri-reforming of methane has been done. The various results and discussions are being enlisted in following sections.

\section{$\mathrm{CH}_{4}$ Concentration Variations With Respect To Time And Length}

Methane being one of the major reactant, in reforming processes follows a decreasing trend in concentration with respect to time \& length (fig 4.1, fig 4.2). Methane concentration profile cab be explained by the backward equilibrium shift of the reaction since, tri-reforming of methane is slightly exothermic in nature. hence, results in a decreasing trend in concentration of methane with respect to time and length of the reactor. But the decrease in concentration of methane during steam reforming can be explained in terms of forward equilibrium shift since the process is endothermic in nature $(\Delta \mathrm{H}=206.3 \mathrm{~kJ} / \mathrm{mol})$, the equilibrium shifts in forward direction resulting in falling trend in concentration profile with respect to time and length of the reactor. A similar argument can be stated in favor of dry reforming i.e. due to endothermic nature of reaction $(\Delta \mathrm{H}=247.3 \mathrm{~kJ} / \mathrm{mol})$ the reaction equilibrium shifts towards forward direction and hence, results in a decreasing trend in concentration profile. While the decrease in concentration of methane during partial oxidation of methane can be explained in terms of the exothermic nature of reaction favors the backward shift of reaction equilibrium, hence, results in a decreasing trend in concentration of methane with respect to time and length of the reactor.

\section{$\mathrm{CO}_{2}$ Concentration Variations With Respect To Time And Length}

Carbon Dioxide follows a decreasing trend in terms of concentration with respect to time and length as it is one of the reactant in reforming processes (fig 4.5, fig 4.6). Trireforming of methane can be explained by the backward equilibrium shift of the reaction hence results $\mathrm{CO}_{2}$ concentration decreasing trends with respect to time and length of the reactor. But the concentration of Carbon Dioxide during steam reforming can be explained in terms of the equilibrium shifts in forward direction resulting in decreasing trend in concentration profile with respect to time and length of the reactor.

\section{$\mathrm{H}_{2}$ and CO Concentration Variations With Respect To Time And Length}

The concentration of hydrogen and carbon monoxide follows an increasing trend as these are the major products of reforming processes (fig 4.9, fig 4.10) and (fig 4.11, fig 4.3.12). From the plots it can be seen that the $\mathrm{H}_{2}$ and $\mathrm{CO}$ concentration are increasing with time and length with respect to methane conversion. This increasing trend can be explained on exothermic nature of try reforming and partial oxidation of methane reforming which shifts the reaction in backward direction.

$\mathrm{CO}_{2}$ Conversion: The $\mathrm{CO}_{2}$ Conversion with respect to time is found to be $67.83 \%$ in case of Tri-reforming. Also, the percentage conversion of $\mathrm{CO}_{2}$ via plots of conversion versus reactor length is found to be $69.97 \%$, It indicates that maximum $\mathrm{CO}_{2}$ conversion is obtained in Tri-reforming process which is much higher than the other reforming processes. The $\mathrm{H}_{2}$ : CO Ratio is found to be in range of 1.11.97 for Tri-reforming of methane while dry reforming of methane the shows a trend of $\mathrm{H}_{2}$ : $\mathrm{CO}$ ratios lower then 1.the 
range for partial oxidation varies from1.1-1.7 as reported in literature. It should be pointed out that the $\mathrm{H}_{2}$ : $\mathrm{CO}$ ratio in synthesis gas is important since synthesis gas with different $\mathrm{H}_{2}$ : $\mathrm{CO}$ ratios have different applications in industry.

\section{CONCLUSIONS}

The Tri reforming of methane was studied from modeling and simulation point of view in a fixed bed reactor using nickel $/ \gamma-\mathrm{Al}_{2} \mathrm{O}_{3}$ catalyst to convert natural gas into syngas. An alternative reforming process of natural gas and flue gases based on the methane conversion was studied combining steam and dry reforming and partial oxidations of methane. The kinetic evaluation of the process indicated that the methane decomposition produced carbon deposition and hydrogen. . They were solved simultaneously using ordinary differential equation solver "ode 45" in MATLAB 9.0 .

Moreover, tri-reforming of methane can be achieved successfully with high conversion $(>97 \%)$ and high $\mathrm{CO}_{2}$ conversion $(>67 \%)$ for producing syngas with desired $\mathrm{H}_{2} / \mathrm{CO}$ ratios of 1-2 over supported nickel catalyst at $1123 \mathrm{~K}$ under atmospheric pressure. The tri-reforming of methane is a challenging technology and requires more research work like energy management, effective conversion of $\mathrm{CO}_{2}$, fuel savings, $\mathrm{CO}_{2}$ emissions and integration of the new process for industrial scale applications.

\section{REFERENCES:}

[1] Alberto M. Becerra, María E. Iriarte and Adolfo E. Castro-Luna,2003"Catalytic Activity of a Nickel on Alumina Catalyst in the $\mathrm{CO}_{2}$ Reforming of Methane", React.Kinet.Catal.Lett.,79, 119-125.

[2] Chunshan Song and Wei Pan,2004," Tri-reforming of methane: a novel concept for synthesis of industrially useful synthesis gas with desired $\mathrm{H}_{2} / \mathrm{CO}$ ratios using $\mathrm{CO}_{2}$ in flue gas of power plants without $\mathrm{CO}_{2}$ separation," Prepr. Pap.-Am. Chem. Soc., Div. Fuel Chem. 49 (1), 131

[3] M. Halmann and A. Steinfeld,2006," Fuel saving, carbon dioxide emission avoidance, and syngas production by tri-reforming of flue gases from coal and gas-fired power stations, and by the carbothermic reduction of iron oxide", Energy, 31, 3171-3185

[4] M. Halmann and A. Stenfeld,2006," Thermo neutral trireforming of flue gases from coal and gas-fired power stations", Catal. Today, 115, 170-178.

[5] M. Halmann and A. Steinfeld ,2009,'Hydrogen production and $\mathrm{CO}_{2}$ fixation by flue-gas treatment using methane tri-reforming or coke/coal gasification combined with lime carbonation", Int. J. of Hydrogen Energy, 34, 8061-8066
[6] Leonardo J. L. Maciel , Aleksandros E. A. M. de Souza,Valderio O. Cavalcanti-Filho, Augusto Knoechelmann, A. M. Cesar de Abreu,2010," Kinetic evaluation of the tri-reforming process of methane for syngas production", Reac. Kinet. Mech. Cat., 101,407416

[7] Wei Pan, Jian Zheng, Chunshan Song,2002," Catalytic Tri-reforming of Methane Using Flue Gas from Fossil Fuel-based Power Plants," Fuel Chem. Div. Preprints, 47(1), 264

\section{NOMENCLATURE:}

$\mathrm{k}_{\mathrm{i}}(\mathrm{i}=1,2,3 \ldots \mathrm{n})$-Kinetic parameters of the step reactions of reforming process

$\mathrm{K}_{\mathrm{i}}(\mathrm{i}=1,2,3 \ldots \mathrm{n})$-Equilibrium parameters of the step reactions of reforming process

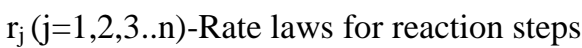

$R_{j}(j=1,2,3 . . n)$-Mass balance equations for the components

$\mathrm{X}_{\mathrm{i}}(\mathrm{i}=1,2,3 . . \mathrm{n})$-Conversion of components

$P_{i}(i=1,2,3 . . n)-$ Partial Pressure of components

$\mathrm{P}=$ Total Pressure of the System

$\mathrm{C}_{\mathrm{i}}(\mathrm{i}=1,2,3 . . \mathrm{n})$-Concentration of components

$F_{i}(i=1,2,3 . . n)-M o l a r$ Flow Rate of components

F-Total Flow Rate of Feed

$r$-Radius of the reactor

z- Length of the reactor

$\mathrm{t}=$ time

CO - Carbon Monoxide

$\mathrm{CO}_{2}$ - Carbon Dioxide

$\mathrm{H}_{2}$ - Hydrogen

$\mathrm{H}_{2} \mathrm{O}$ - Water

$\mathrm{CH}_{4} \quad$ - Methane

$\mathrm{O}_{2} \quad$ - Oxygen

TRM - Tri-reforming of methane

SRM - Steam-reforming of methane

DRM - Dry-reforming of methane

POM - Partial oxidation of methane 